DOI: https://doi.org/10.32839/2304-5809/2020-78.1-23

UDC 372.881 .1

Ryzha Anastasiia, Krasilnikova Olha

Ivan Franko National University of Lviv

\title{
INTERACTIVE TEACHING METHODS AS AN EFFECTIVE TOOL OF FOREIGN LANGUAGE ACQUISITION
}

\begin{abstract}
Summary. The main objective of this article is to examine the methods of English for Specific Purposes (ESP) as a part of English language teaching and to introduce various activities aimed at enhancing vocabulary, speaking, and writing skills. The article contains theoretical background concerning ESP, its definition grounded on different theories and special features connected with ESP discipline (organization of an ESP course, proper selection of teaching materials, types of activities, teacher's role, evaluation and motivation of students). The topicality of the article lays in the fact that teaching the learners professional English based on innovative methods and techniques makes a process of learning the language more sufficient, and the usage of these aids motivates the learners to pay more attention in class and they can relate their learning with their real life. The innovative methods and techniques in teaching English to the employees in hospitality industry is the object of our article.
\end{abstract}

Keywords: ESP, innovative teaching, real-life learning, learners' needs analysis, method of case study.

Рижа А.В., Красільнікова О.М.

Львівський національний університет імені Івана Франка

\section{ІНТЕРАКТИВНІ МЕТОДИ ВИКЛАДАННЯ ЯК ЕФЕКТИВНИЙ ІНСТРУМЕНТ ЗАСВОСННЯ ІНОЗЕМНОЇ МОВИ}

Анотація. Ця наукова розвідка має на меті проаналізувати важливість використання інноваційних методів і прийомів у навчанні англійській мові фрахового спрямування для студентів гуманітарних фракультетів. 3 цією метою було проаналізовано декілька методик викладання англійської мови як мови фраху, що були запропоновані відомими лінгвістами. Викладання англійської мови фрахового спрямування English for Specific Purpose (ESP) е складним процесом, що потребує врахування широкого спектру фракторів. Стиль та методи навчання ESP достатньо відрізняються від загального навчання. Попри низку досліджень у сфері методики викладання іноземної мови фрахового спрямування, велика кількість питань залишаються не достатньо висвітленими та аргументованими, що підтверджує актуальність цієї публікації. Зі збільшенням обсягів тематичного наповнення навчальних планів для викладання іноземних мов фахового спрямування, ключовим завданням викладача $є$ вичерпне розуміння мети такого навчального курсу та правильний відбір матеріалу для аудиторної та самостійної роботи студента. У групі студентів, які вивчають ESP, викладач сам повинен вибрати відповідні методи навчання та види діяльності, які сприятимуть активній взаємодії студентів. Ключовим об’єктом викладання та навчання у будь-якій групі $є$ студент, той хто навчається, тому в статті були представлені різні категорії цільової аудиторії, які демонструють той факт, що всі студенти, які навчаються в рамках ESP, повинні мати певний рівень володіння англійською мовою. Саме тому в цій роботі розглядаються різні фрактори, головним чином аудиторія, мета, підходи та методи навчання, які можуть бути найдоцільніші в конкретній ситуації. Для викладання англійської мови фахового спрямування, варто знати конкретні цілі аудиторії, завдання поточного курсу та сфери реалізації засвоєного мовного матеріалу. Особливість організації процесу вивчення ESP полягає у необхідності створювати атмосферу реальних професійних ситуацій в аудиторії та вмотивовувати учнів брати активну участь у їх вирішенні. Увага приділена формуванню професійних мовних навичок.

Ключові слова: англійська мова фрахового спрямування, інноваційні методи виклання, кейсові методи навчання, аналіз потреб аудиторії.

Droblem statement. The topicality of present piece of work lays in the fact that teaching English to learners with the purpose to implement it in their career with the help of innovative methods and techniques makes a process of learning the language more sufficient, and the usage of these aids motivates the learners to pay more attention in class and they can relate their learning with their real life.

Recent research and publications. The paper is based on the works by well-known scholars and theoreticians in the sphere of English teaching methodology, among them the works by Tom Hutchinson and Alan Waters, Gary Motteran, Hans Mol and others.

The purpose of the article. The current article is an attempt to explore the phenomenon of innovative methods and techniques in the process of devel- oping productive language skills of the ESP learners on the basis of the analysis of different pedagogical methods and the activities based on them.

Presentation of the main material. Organizing the ESP course is a very important step to achieve a satisfying goal in the course. There is quite a big range of factors playing a vital role in organizing an ESP course, as without them the learning process would not lead to effectiveness. The term "specific" in ESP refers to a specific purpose for which English is learnt and the teacher should be aware of. He or she should find an answer to what T. Hutchinson and A. Waters describe as "language description". The "language description" involves such questions as: "What topic areas will need to be covered?", "What does the student need to learn?", "What aspects of language will be needed and how will they be described?" [1, p. 17]. Finding correct 
answers to these questions results in organizing clear and exact objectives of the course. It is natural that learning strategies vary and correspond with the learners' groups, their age, level or reason they study English. The way adults master a language is different from that of children, the group of advanced learners expects to have a different attitude of the teacher than the group of beginners. The ESP teachers should determine the focus of the ESP course to meet the learners' needs and expectations successfully. T. Hutchinson and A. Waters stress one more aspect affecting the ESP course, it concerns the learners' surrounding and the nature of a particular target and learning situation. They describe them as "needs analysis" to organize the ESP course effectively and consequently achieve a satisfactory goal [1, p. 24]. The learner and the way of learning ('acquiring language') are considered to be the main factors in the whole process. T. Hutchinson and A. Waters emphasize ESP to be an approach, not a product, which means that language learning not language use is highlighted. They draw attention to a 'learning-centered approach' "in which all decisions as to content and method are based on the learner's reason for learning" [Ibid, p. 38].

The ESP course is to meet specific needs of the learners: 1) it is closely related to the content (special description, occupations, and activities); 2) it is centered on the language appropriate to those specific professional activities in syntax, lexis, discourse, semantics, etc.; 3) it is designed for adult learners, either at a tertiary level institution or in a professional working environment; 4) it is aimed at intermediate or advanced learners. Most ESP courses assume some basic knowledge of the language system, but it is mostly used with the beginners [2, p. 142].

It is also important to give the students the knowledge of the global society we live in and to consider things holistically. Problem solving is an important aspect here. Teaching methodology should include the aspect which provides a more effective opportunity for students to internalize and make sense of what they are taught relating to their future field of work. A methodology centered on problem solving is required in any industry or field of work which deals with serving customers

A wide variety of foreign language teaching methods were developed in the $20^{\text {th }}$ century. This fact has strongly influenced the process of language teaching and learning. Interactive methods are considered to be most effective. Interactive methods are as follows: communicative language teaching, direct method, language immersion, natural approach, proprioceptive language learning method, silent way, storytelling, and suggestopedia. Let's consider some of them in more details.

The proprioceptive language learning method is a language learning technique which emphasizes simultaneous development of cognitive, motor, neurological, and auditory functions as all being part of comprehensive language learning process. The silent way is a methodology of teaching a foreign language based on the idea that the teachers should be as silent as possible during a class but the learners should be encouraged to speak as much as possible. Suggestopedia is an effective comprehensible input based on a combined method of desuggestion and suggestion to achieve super learning. The most im- portant objective of suggestopedia is to activize the students' mental potential to learn that is obtained by suggestion. Desuggestion means unloading the memory banks, or reserves, of unwanted or blocking memories. Suggestion then means loading the memory banks with desired and facilitating memories.

Communicative language teaching (CLT), also known as the Communicative Approach, emphasizes interaction of both the means and the ultimate goal of learning foreign languages. This method puts emphasis on correct pronunciation and the target language. It advocates teaching of oral skills at the expense of every traditional aim of language teaching. The method relies on a step-by-step progression based on question-and-answer sessions which begin with naming common objects such as: table, menu, waiter, restaurant, etc. It provides a motivating start as the learner begins using a foreign language almost immediately. Lessons progress to verb forms and other grammatical structures (table - to book a table; menu - ask for a menu; waiter - tip a waiter) with the goal of learning about thirty new words per lesson. The communicative approach attempts to make all the activities as much life-like as possible by using authentic materials, which can be considered as a methodological improvement.

The method of case-study or specific situations is a method of active problem-situation analysis based on learning by addressing specific problems - situations [3, p. 161]. This method refers to the non-gaming simulation active training. The immediate objective of the method of the case-study consists in the following: a group of students work together to analyze the situation - a case, which occurs in a particular situation, and work out a practical solution, the end of the process is evaluation of the proposed algorithms and the selection of the best one in the context of a given problem. Case-studies are training specific situations specially developed on the basis of factual data for subsequent analysis in the classroom. In the case study students learn to work in "a team", to analyze and to make management decisions. The method of case-study is a tool to apply the theoretical knowledge to solve practical problems. The method promotes the students' critical thinking, the ability to listen to and consider an alternative point of view to express their arguments. With the help of this method, students have the opportunity to demonstrate and improve their analytical and evaluative skills, learn to work as a team to find the most efficient solution to the problem.

Project method is one of modern methods of teaching in which the student's point of view is given importance in designing the curricula and the content of studies. It takes the student beyond the walls of the classroom. It is carried out in a natural setting, thus, making learning realistic and experimental. Also, it encourages investigative learning and solution of practical problems as it is focused on the student. Moreover, it encourages the spirit of scientific interest as it involves validation of hypotheses based on the evidence got [4, p. 622]. Comparing with books it promotes a better knowledge of the practical aspects. There is one great advantage that makes this method worth using - it enhances the students' social skills, as it requires interaction with the social environment. 
With the invention of the Internet and its everyday accessibility, the traditional classroom of four walls has been torn down. The use of online social networks promotes active language learning as both teachers and learners can participate in a "collaborative learning environment" which provides opportunities for interaction and thereby helps in language socialization, it also provides a platform to the learners to use the target language outside classroom for practical interaction purpose. In these ways, Facebook creates great opportunities for learners to understand the social practices embedded in language and apply them in real life.

Conclusion. The recent growth of information and communication technologies, advanced requirements at work has led to an urgent foreign language acquisition. Nowadays, the knowledge of English has become a top demand on a job requirements list. Moreover, English is perceived as a fa- cilitating tool in a modern professional life. Such situation is quite beneficial for both the teachers and students. Students are highly motivated to enhance their language skills as they can easily use or implement in their work what they have learnt in their English class. On the other hand, the teacher's understanding of the students' needs makes it possible to structure the studying process meeting all the students' requirements. Choosing materials for a language course determines the structure of the course and underlines the content of each lesson. Appropriate techniques and methods of teaching should help teacher in organizing the course or what is more, they can support teachers and learners in the process of learning [5, p. 107]. Usage of any language teaching innovative method for language learners who deal with the same broader field of language usage but are different in their specializations will be very effective.

\section{References:}

1. Hutchinson T., Waters A. English for Specific Purposes: A learning-centered approach. Cambridge: CUP, 2006.182 p.

2. Bojović M. Teaching Foreign Language for Specific Purposes. Teacher Development. The $31^{\text {st }}$ Annual ATEE Conference. 2006. Pp. 482-487.

3. Brown H. D. Teaching by Principles: An Interactive Approach to Language Pedagogy. San Francisco: Addison Wesley Longman, Inc, 2001. 416 p.

4. Nicolaides A. Innovative teaching and learning methodologies for higher education Institutions. International Research Journals, 2012. Pp. 620-626.

5. M. Butler-Pascoe. English for Special Purposes (ESP), innovations and technology. English Education Journal, 2009. Issue 3. Pp. 109-115. 